\title{
Developing "CH-CD Electrolyte Solution Test Tools" Game for Teaching Spoken Procedure Text to Twelfth Graders of Senior High School
}

\author{
Erna Setyawati ${ }^{1}$
}

'SMAN 11 Semarang, Semarang, Indonesia

Contact: Ernasetyawati $\otimes$ pinkysadlyagmail.com

\section{ABSTRACT}

The objectives of this research were to develop "CH-CD Electrolyte Solution Test Tools" Game for Teaching Spoken Procedure Text to Twelfth Graders of Senior High School. The subjects of this research were XII MIPA 2 and XII MIPA 6 SMAN 11 Semarang students in the academic year of 2016/2017. The process of this research was conducted in seven stages. The data were analyzed by using qualitative and quantitatives methods. The researcher used t-test formula to analyze the data. Principally, the object of R\&D is managing and developing the effectiveness of product applied at schools. The researcher gives the name of this game by own words, it is " $\mathrm{CH}-\mathrm{CD}$ Electrolyte Solution Test Tools" game.The result of the research shows that "CH-CD Electrolyte Solution Test Tools" game can develop students' speaking ability. This successfulness can be seen from the result of increasing students' average score and good responses by studentsafter practising "CH-CD Electrolyte Solution Test Tools" game. The result of the research can be concluded that by using " $\mathrm{CH}-\mathrm{CD}$ Electrolyte Solution Test Tools" game in teaching spoken procedure text, teacher can improve students' ability in speaking. And it is hoped that it can be valuable as the information resource for all people.
\end{abstract}

\section{KEYWORDS:}

Research and Development; Speaking;

Procedure text;

Ch-cd electrolyte Solution

Test Tools;

Game

\section{Introduction}

Richards (2008) stated that the mastery of speaking in English is a priority for many second-language or foreign-language learners. Consequently, learners often evaluate their success in language learning as well as the effectiveness of their English course on the basis of how much they feel they have improved in their spoken language proficiency. Students need to practice their skill every day to improve their speaking ability. Therefore, teacher should give students opportunity to practice their speaking by giving more examples, activities, methods, and also media that put them into real practice communication.

Speaking needs to be practiced continuously, but sometimes students find a problem when they practice speaking. They cannot devote their ideas orally well and their speech cannot be understood. It is also halting, slow, and fragmentary. This problem cannot be separated from technique, approach, 
method, and also media used in teaching English especially teaching speaking. Therefore, teacher is suggested to prepare these components especially media for teaching.

Language is very important in our social life, without language a human being can not convey a message to each other. They can not order something to fullfill their necessity. Language is a tool of communication. Communication is the exchange and negotiation of information between at least two individuals through the use of verbal and non-verbal symbols, oral and written/visual models and production and comprehension process (Richard, 1983:7). People can express their ideas and wishes to other people by language. The language plays a very important role in human life. Without language, human can not speak to others or deliver their message and there is no communication in this world.

Students in Indonesia need a lot of character building education from the teacher, parents, environment; many of us believe that learners have certain characteristics which lead to more or less successful language learning. There are many factors generally considered to be relevant to language learning, such as intelligence, creative, aptitude, motivation and attitudes. Another important factor is the age at which learning begins. Effective character education is not adding a program or set of programs to a school in each region. It is a transformation of the culture and life of the school, through the English language education. In this research the researcher wants to build the character of the students in Indonesia in order to have courage to convey their goal through the speaking of procedure text.

The act No. 20 article 1 of 2003 mandates that Education is a conscious and deliberate effort to create an atmosphere of learning and the learning process so that learners are actively developing the potential for him/her to have religious spiritual power, self-control, personality, intelligence, good character as well as skills required by themselves, the notion and state of society. So in every lesson, we begin by asking the question, "What can we do during the learning session to create a student who does not have the qualities or skills in order he/she learns how to get it. In line with the law, then the character education program was launched as a national program by the Government of Indonesia on May 2, 2010 and currently it has become a hot issue in curriculum development in 2013. Therefore, it was important to assist teachers in implement interesting lesson and pays attention to character education at the same time in order to obtain qualified graduates in a school. The school is a caring community of learners in which there is a clear bond connecting the students, the staff, and the school.

Every teacher in Indonesia is required to integrate character education in each lesson in the classroom, extracurricular and in the school environment. It is intended to make students acquire character education as a whole and integrated with all subjects included in the English lessons so that finally they can put it into practice in their real life as a good human being. English teachers 
are challenged to realize it in the process of learning, despite many obstacles that may be encountered. Given the existence of the fact that most of the young people tend to do the opposite things such as doing pre-marital sex, abortion, addicted to pornographic films, consuming psychotropic substances, etc., then the integration of character education in the learning process should be realized within the lesson plans, materials and evaluation.

However, not all teachers are aware the importance of the integration of character education in the lesson that should be realized in teaching materials or perhaps because they don't understand how to integrate it. Senior High School students who are obligate to get English lesson starting from the first semester are students in searching for identity status, hence besides obtaining English lesson they would at once receive the intervention of character education of English teacher in order to have good habits so that they become graduates of Senior Highschool which have noble or good character. The education emphasized the cooperation and collaboration among students over competition. Values such as fairness, respect, and honesty are part of everyday lessons in and out of the classroom. Students are given ample opportunities to practice moral behavior through activities such as service learning. Discipline and classroom management concentrate on problem-solving rather than rewards and punishments. The old model of the teacher-centered classroom is abandoned in favor of democratic classrooms where teachers and students hold class meetings to build unity, establish norms, and solve problems.

Based on early monitoring, the researcher knows that learning English language is an exhausting work to both teacher and students. English is the most difficult and bore lesson in the school, so the students cannot enjoying the lesson. Learning foreign language will be easier if the students can enjoy and be comfortable during the lesson, so they can understand the lesson easily. First step is they have to be attracted to the lesson. Talking about the procedures text lesson, it is one of the text types taught at Senior High School level. It seems as a simple thing at the surface, but it is a big problem for both the teacher and students if they meet inappropriate method for it.

There are many things which can be done by teachers to make the language instruction more challenging and interesting. Among others use of realia, pictures, photos, cards, chain message, games, and songs as well as more innovative techniques. Teaching English is very exciting, especially teaching of speaking, it is very easy to make the students follow the materials well. Teaching speaking is very exciting when the teacher can perform an interesting object or media of learning, so in this case the researcher wants to research and develop an interesting object or media into the study in procedure text materials. So, to encourage this research and development, the researcher has to prepare the lesson study that consists of fun activities in it.

Using realia is the way to make the students motivated to speak in English. Based on the need analysis in the field, there are a lot of students who like discuss to about procedure text related their favorite isotonic drinks. They like 
many isotonic drinks in their life, and the researcher observes that there are a lot of isotonic drinks around them, which are sold free, but they don't know whether it contains of dangerous substances or not. The evidence of researcher' observation is there are a lot of students who consume isotonic drinks in their life. Based on this fact, the researcher creates "Electrolyte Solution Test Tools" media to practice learning speaking of procedure text about how to know or check whether their favorite isotonic drinks contain electrolyte solution or not. So, the researcher uses realia to practice speaking of procedure text. The researcher uses a chemistry test tools to make an interesting media of procedure text, it is " $\mathrm{CH}-\mathrm{CD}$ Electrolyte Solution Test Tools" game. It is used to practice "procedure text" about "how to check electrolyte solution in Mizone", "how to check electrolyte solution in Coolant", "how to check electrolyte solution in Pocari Sweat" and other ion supply drinks or isotonic drinks. It can increase the motivation of students to speak in English.

Based on need analysis the students like to study English in group, outdoor, use the media, games, have fun and the subject has good character education to the students. So, researcher uses the interesting instructional materials that contain fun activities to realize good character as well as the knowledge and English skills so it can be integrated in everyday behavior when using English.

Basically, those difficulties of transferring speaking knowledge often exist in the real process of teaching and learning at school. That was what the researcher found while doing observation in XII MIPA 2 and XII MIPA 6 graders of Senior High School 11 Semarang. As the first step of need analysis, the researcher did some interviews, gave the questionnaire, and observed the class activity. Then the researcher found out that students of twelfth grade of those schools feel that speaking was not taught successfully enough. The common problem is that only few interesting activities applied. In fact, teacher's book as well as student's book had given unsupported material for them. They did not give interactive approach to reach an interesting way of conducting speaking of procedure text. Identifying such difficulties and being consciously aware of them has driven the researcher to find ways of overcoming them and provide effective speaking instruction. It also becomes a challenge for the researcher to develop it in funny and meaningful way.

SMAN 11 Semarang has applied The Curriculum of 2013 for all classes. One of the considerations why the researcher chooses the twelfth grade to be observed is that procedure text is taught at this grade in the Curriculum of 2013.The other reason is the researcher try to provide teaching aid to succeed a meaningful way of learning speaking of procedure text. The researcher realizes that teacher needs preparation in applying the Curriculum 2013 especially for the next academic year, in which the twelfth students are already exist to be taught. Here the researcher modifies the "Electrolyte Solution Test Tools" to be used to teach speaking of procedure text. 
The original realia is "electrolyte solution test tools" which can practice individual, in pairs, or in group, and the researcher make the combination of original realia with chain message and cards in group as a game to make new fun activities in procedural text material, and the researcher give the name of this game by own word, it is "CH-CD Electrolyte Solution Test Tools" game that contains of procedure text material. $\mathrm{CH}$ is abbreviation of Chain, and CD is abbreviation of Cards. So, on the other hand, it can be said that it is Learning of Speaking English of Procedure Text material about how to know or check electrolyte solution in isotonic drinks through chain message and card game using "CH-CD Electrolyte Solution Test Tools" game. Through this game students will comprehend the speaking easily in a fun way. Finally the purpose of speaking of procedure text will be reached since students could apply their knowledge of speaking to the text.

And then, the book used for student is "Pathway". The researcher has found that the book still needs improving. There are still limited materials and communicative activity given, which encourages student to speakin a good pronunciation. It is known that the material of procedure text for Senior High level are mostly about how to make something, usually they are dealing with food or simple thing making. Those are discussing what students usually do in daily activity.

To help students and teachers gain a better understanding and enhance teaching and learning process, it is believed that fun lesson were intended to show that creative meaningful change and innovative planning are possible and welcome in the English language classroom. Today, it becomes a must for students to study in relax and comfortable environment in which student feel free to express and explore their ability. Through some interviews, some twelfth grade students of SMAN 11 Semarang shared that they could not obtain the essence of speaking, instead of sentence analysis and pattern memorizing. The book provides some activities of learning procedure text, like demonstrating the simple making of snacks or beverage, playing kite, doing a simple steps of using credit card, applying a hotel chip, or battery of a mobile phone. However, they did not improve their speaking skill of using a good language structure in an interesting way.

The previous study, Nurhasan (2011) conducted on speaking procedure text using picture. It concerns to make the students fun to study speaking material of procedure text. The picture are able to give information about the instructions in speaking procedure text, though by looking at the pictures students are easier to tell the materials and the steps, and also pictures can develop students ideas in speaking procedure text.

The second study was conducted by Siti Aulia Febriyanti and Tina Mariany Arifin, it concerns to use video in order to improve the students' speaking competence in reporting a procedure text, the findings of the study indicate that using video significantly improved the students' speaking competence. 
So, in this research, the researcher developed " $\mathrm{CH}-\mathrm{CD}$ Electrolyte Solution Test Tools" Game For Teaching Spoken Procedure Text to Twelfth Graders of Senior High School. The teaching of spoken procedure text material is in accordance with 2013 curriculum, and "CH-CD Electrolyte Solution Test Tools" game can be used to strengthen Senior High School Student's character education.

The English teachers need to describe the appeal of government to integrate the English lesson with character education which are good and fair. The entire document should be synchronized with the appeal included the design fun activities based speaking material of procedure text that are integrated with educational character based, making learning more interesting and the results will last longer in the memory and strengthen the students' character education. The researcher chooses learning of procedure text because it is in the twelfth grade Senior High School curriculum. The students are considered English language learners in formal beginners, so in accordance with the opinion that the faster in doing the intervention to implement character education in English language learning through fun activity in speaking of procedure text. However teacher still faces difficulty on ineffective text book used by twelfth grade dealing with the speaking of procedure text. Since the book is lack of creative activity, while students need fun and innovative way to understand speaking easily. Therefore, the researcher intends to create a teaching material dealing with the speaking of procedure text which contains a speaking game. It is called as " $\mathrm{CH}-\mathrm{CD}$ Electrolyte Solution Test Tools" game. The game offers participants do not only comprehend the speaking in a fun way, but also study how to understand and speak of procedure text successfully.Borg dan Gall (1983, p. 772) explain that product refers to not only in object materials, such as text book, learning film, but also in procedural and process, like learning methods, or methods to organize learning teaching process.

Speaking is the utterance of intelligible speech, it is also speech production. (AS Hornby, A.S.Oxford Pocket Learner's Dictionary, 2000, p. 443). Speaking is ability say articulations sound or words to express or to submit mind, feeling and idea. Speaking is ability which is used for communication in daily activities. People send and receive message through speaking. They give reports, idea, advise, instructions, complaint, apologize, agree, disagree and so much means by speaking. The major goal or English learning is to enable students to communicate with other people by using engling language being learned. The communication here means to talk to other people orally in spoken form. So what does speaking mean, it means a process using a language that is done by speakers by combining both codes and message.

Procedure text can be used in learning teaching process by fun activity, procedure text can be taught through listening, speaking, reading, vocabularies, and writing. Creating a text requires us to make choices about the words they use and how they put them together. If students make the right 
choices then they can communicate with others. Our choice of words will depend on our purpose and our surroundings or context (Anderson: 1).

As procedure, therefore, is a piece of text that gives us instructions for doing something (Anderson, p. 50).Thus, from this explanation, the researcher concludes that procedure text is any meaningful stretch of language in oral and written that has social purpose to describe how something is accomplished through a sequence of actions or steps.

Based on Palanova (2010, p. 8), "Game is that of an enjoyable activity involving an objective that is achieved by following certain rules, usually in competition with one or more other people". However, because this is done in a context of a game, they relax and forget that they are being watched. They often become so involved in the game that they stop feeling anxious about their mistakes. Bringing games into the classroom can be a great way to creatively engage students with their learning and have fun while taking a break from the usual classroom routine. Use games to work on new material, review topics before a test or exam or just give students the chance to practice what they're learning in a fun way.

It is important to make character development a goal for teenagers. While this may sound like a difficult task, it can be made more enjoyable by employing games, activities and discussions to teach teenagers traits and qualities of good character as well as decision-making skills under difficult circumstances. Often, a teenager's success is bound up in his character; we can help the students be successful in developing good character.

Character education is set a guideline or minimum traits for schools or teachers to develop their own that have as one of their objectives promoting the character development of students. The character is defined by what we do, not what we say or believe. Character education can be implemented in fun activity. Learning teaching activity using fun activity strengthen students, character education, such as: National education development established 20 main characters to be developed in order to create better generation since recently there are so many bad habit that seem to be excused by people as systemic corruption in department and violence in teenagers life, affection, discipline, economize, no surrender, fair, positive thinking, independence, peace, tolerance, emotion control, citizenship, responsibility, creative, care, good manners, enthusiasm, brave, self-confidence, b hard-working and collaboration (Depdiknas, 2009:9-13)

"CH-CD Electrolyte Solution Test Tools" game which is developed here is a modification of the existing original and interesting "Electrolyte Solution Test Tools"science experiment. It is modified to play about speaking containing in a procedural text, they are Simple Present Tense, connective of sequence, Noun Phrase, numbering (ordinal number), and imperative verb, the use of adverbs, the social function of procedure text, and generic structure of procedure text which are used to reach the goal of speaking procedural text in a good speaking. It will be played the students. There will be cardsand chain 
message provided with English vocabularies. The purpose of the game is to make procedure text material in learning of speaking run in fun activities, and the researcher completed the media with Alternating Current, Direct Current, sound and lamp flame to make the procedural text more fun.

Chain message is very effective to give the students happy fun in their lesson. Bob Blain, Ph.D. Emeritus Professor of Sociology at Southern Illinois University Edwardsville said that one link in an information chain occurs when one person communicates with another person: $A-->B$.

$A$ second link occurs when some of that information is relayed to a third person: $A-->B$--> C.

Chains continue to lengthen as long as some of the information that originated with A continues to survive the communication process (Bob Blain, rblain@siue.edu. 2015)

The two problems of information chain communication are entropy and volume. Entropy refers to the tendency of all messages to be distorted as they pass from person to person. Volume refers to the length of messages. The more details in messages, the more effort people must expend receiving, interpreting, and relaying them.

To increase information chain length and, thus, to enlarge the scale of cooperation, ways had to be invented to reduce both message entropy and volume. The independent variables vary in entropy and volume.

\section{Method}

The study used Research and Development approach; the objectives of the study designed and innovated to the procedure text materials with fun activities for twelfth students of Senior High School. According to Borg and Gall $(1983$, p. 772$)$ research and development $(R \& D)$ is one research design aimed at developing and validating educational products. The process involves identifying problems that need to be solved by educational product, like textbook, syllabus, assessment instrument, etc., studying the principles of writing instructional media, developing the media based on the principles, field testing it in the setting where it will be used eventually, and revising it to correct the deficiencies found in the field-testing stage.

In this study, the writer will use research and development. The study is an activity to solve problems related to education in life issues. 


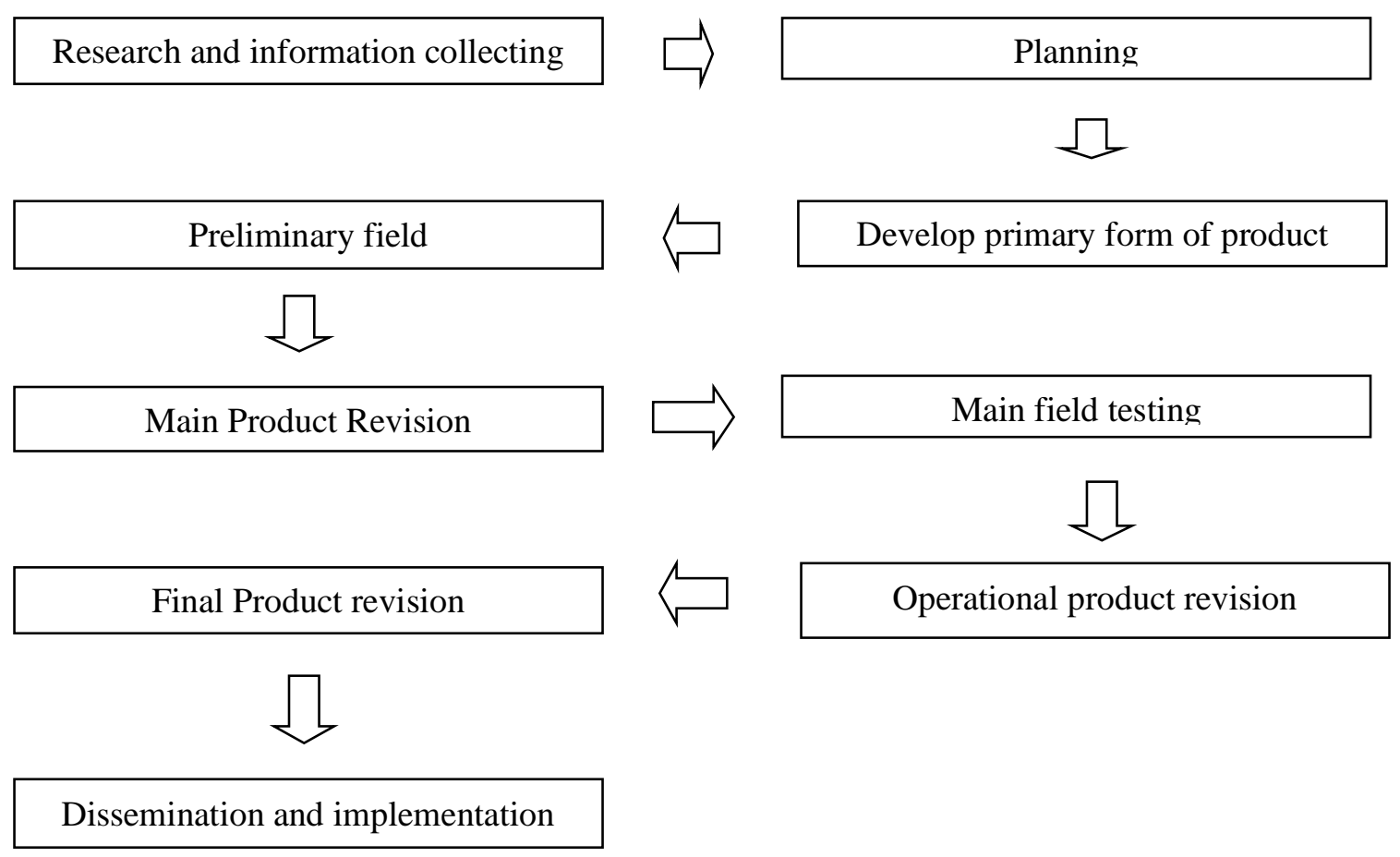

Figure 3.1Developing procedure scheme of adaptation result in

Developing procedure of Borg \& Gall (Borg \& Gall, 1983:775)

Material Development Model adapted from Borg and Gall (1983, p. 775)to develop speaking material is used to teach English, namely procedure text containing fun activities to strengthen character education of the twelfth grade Senior High School students. The research and development of Borg and Gall $(1983$, p. 775$)$ is conducted in ten steps, but the researcher reduced the steps from 10 to only 7 steps. They were:

a) Conducting the survey

b) Planning

c) Developing material

d) Doing first revision

e) Trying out

f) Doing second revision

g) Producing the final product

The subject of this research is twelfth grade of Senior high school students and the English teacher. The twelfth grade students of Senior high school will be observed by the researcher about the students' need in speaking material. After developing the speaking materials the writer will give the try out to the students to know the effectiveness of the product. Besides that the writer will take the data from the English teacher through the interview him/her.

The subjects of this research consist of 78 students and 2 English teachers from SMAN 11 Semarang. Those two schools have been implementing the 2013 Curriculum by the time of academic year 2016-2017. Setting is the place 
where the study takes place. The study will be conducted in Senior High School.

The data that will be analyzed is the reality of speaking material of procedure text to strenghten Senior High School Students' Character Education. The data will be taken from observation of need analysis of the students in the field. This research will use fun activities based speaking material of procedure text to strenghten Senior High School students' character education to make a new design of procedure text learning appropriately.

There are several techniques in obtaining the data. According to Saleh (2008, p. 30), there are five ways in collecting the data. They are observation, questionnaire, interview, test, and document study. On the other hand, according to Arikunto (1996, p. 224-234) there are four ways in collecting data. They are test, questionnaire, interview, observation and documentation. Some techniques used in the preliminary research are observation, interview, and questionnaire.

\section{Result and Discussion}

Games which are available for teaching spoken procedure text to twelfth graders of Senior High School were based on the result of interview showed that they used monologue and dialogue when teaching speaking of procedural text and used one textbook, it is Pathwaybut sometimes they searched the material from internet. When using the monologue of procedure text in English textbook, they only speak about procedure text without media and students heard it and when using the dialogue of procedure text, they asked the students to speak with his/ her friends as a partner. After speaking of the procedure text in the monologue and ask the students to speak English in a partner, it would be continued to the discussion, question, and answer method.

It was very boring activity because there are no engaged or fun activities that will make them eager to learn. In addition, the school provided limited facilities and medium in teaching. The teachers said that there is no cassette or $C D$ in the textbook provided by the school to teach speaking. So, they only provided the speaking material using textbook which searched by themselves without inserting fun activities in their teaching. The students were just asked by the teachers to listen and discuss together in speaking material. In accordance with the purpose of the 2013 curriculum, the teachers thought that the speaking material containing fun activities is necessary for students to provide a new nuance for students, increase students' interest in learning to improve students' character.

Games which are needed for teaching spoken procedure text to twelfth graders of Senior High School was based on the result of questionnaire given to the students. The data of the respondents' needs which were gathered through questionnaire. From the result of the need survey through questionnaire, we could see the highest score of the activity on each item. Based on the result of the data, the highest score of activities based on need analysis is fun activities. 
Therefore, the researcher decided to develop speaking of procedural text material containing fun activities. In this case, the researcher will use three kinds of fun activities from the highest score, namely " $\mathrm{CH}-\mathrm{CD}$ Electrolyte Solution Test Tools" game using AC (Alternating Current) and DC (Direct Current) of electrolyte solution test tools.

The "CH-CD Electrolyte Solution Test Tools" game for teaching spoken procedure text to twelfth graders of Senior High School developed into a teaching material, entitled "CH-CD Electrolyte Solution Test Tools" game. The teaching material was developed as well as the lesson plan given through the flow of learning process, which was implemented as the field testing in class. It is in a form of hand book or module. It is completed with the activities for each stages of scientific approach. Starting from the apperception, as the early step to build students knowledge of the material discussed. The Module has some pictures come with the questions as the stimulus of brain storming. For this purpose the book is completed with "CH-CD Electrolyte Solution Test Tools" game as the media of presenting the materials. These were all validated by the experts of English department.

In developing speaking of procedure text material containing fun activities for the twelfth graders of Senior High School, the researcher used Borg and Gall's model and the steps are possible to be modified when running the program. The steps are conducting need survey, planning, developing material, doing first revision, trying out, doing second revision, producing final product.

The "CH-CD Electrolyte Solution Test Tools" game implemented for teaching spoken procedure text to twelfth graders of Senior High School was given to find out which group could deliver right and complete of chain message, match to the cards, and practice to the electrolyte solution test tools. When the group practiced in right test tools, and had complete message based on the researcher's instructions in the message on the paper, active, and that group can performed well, practising the speaking in a good pronunciation, has fluency in speaking, and good accuracy, so, that group is the winner of the game.

The result of spoken assessment is very satisfying. It showed that students' comprehension of procedure text was improving. It could be seen from the result of the post-test. XII MIPA 2 grade of SMAN 11 Semarang got 95.16 for the average, while XII MIPA 6 grade of SMAN 11 Semarang could reach 97.05.The accumulation of all the average, it resulted 96.10. It meant that the teaching material "CH-CD Electrolyte Solution Test Tools" game was completely good. This implies that implementingspoken procedure text material containing " $\mathrm{CH}$ CD Electrolyte Solution Test Tools" gameis effective for the twelfth graders of Senior high school. The treatment given by the researcher in" $\mathrm{CH}-\mathrm{CD}$ Electrolyte Solution Test Tools" game actually has contributed for the development of students' comprehension of procedure text. Hopefully the students also could apply the knowledge to their daily life. 
According to the findings in this research, in the previous chapter, it can be concluded that the post-test scores who were taught by using " $\mathrm{CH}-\mathrm{CD}$ Electrolyte Solution Test Tools" game are higher thanpre test scores before were taught by using "CH-CD Electrolyte Solution Test Tools" game. It was proven by comparing the mean between post-test(95.16) and Pre test (75.64) which is clearly stated by the statistical computation between those two groups. Moreover, based on the table of Paired Samples Correlation output the correlation between pre test and post test are -.081 and the significant shows .664 , so it is indicated that the correlation between pre test and post test are significant. The result of speaking ability of the students showed that most of them are very good in spoken procedure text material. Some of them got excellent scores. It means that most of them were able to speak the language with sufficient structural pronunciation, intonation, accuracy, and fluency to participate effectively in most formal and informal conversation on practical, social, and professional topics.Whereas some of them who got excellent scores level were able to use the language fluently and accurately at all levels normally pertinent to professional needs (Oller: 1979). Therefore, the research question of this study has been answered well.

From the findings above, it can be stated that the Null hyporesearch, which stated that there is no significant difference in the speaking ability of procedure texts between the students who are taught by using " $\mathrm{CH}-\mathrm{CD}$ Electrolyte Solution Test Tools" game and those who are not is rejected. On the other hand, the alternative hyporesearch which stated there is a significant difference in the speaking ability of procedure texts between the students who are taught by using "CH-CD Electrolyte Solution Test Tools" game and those who are not is confirmed. It can be assumed that teaching spoken procedure texts to twelfth graders by "CH-CD Electrolyte Solution Test Tools" game helps the students to create a procedure text orally in a fluent way and reach a higher achievement. If the teacher implements the "CH-CD Electrolyte Solution Test Tools" game to teach speaking of procedure texts, the students will be able to produce oral procedure text not only easily but also well structured and fluently because from the "CH-CD Electrolyte Solution Test Tools" game they will become confident and critical learners, use their previous knowledge for the speaking task, feel free and confident through the game. Through their friends' sentences they will gain new knowledge such as new vocabulary and how to arrange a good procedure text, so that they can produce the oral text well. In conclusion, it can be said that "CH-CD Electrolyte Solution Test Tools" game is one of the effective teaching speaking games that can be used to teach speaking production of procedure text in the classroom or out of the classroom.

The purpose of " $\mathrm{CH}-\mathrm{CD}$ Flectrolyte Solution Test Tools" game is giving a new concept in order to the students feel good when do speaking learning.

Things should be prepared:

1) The outdoor class where all students can do the activityfree. 
2) The material of procedure text, for example: Mizone, Coolant, Pocari Sweat.

3) The paper, pen.

4) "Electrolyte Solution Test Tools"

5) Cards consist of the vocabularies of the procedure text materials.

6) Make sure that the students have understood the topic to be discussed.

The Rule:

1. Divide the students into fivegroups, per group consist of six persons.

2. The activity can be done outside the classroom (outbound activities).

3. Teacher give the materials of procedure text in the paper as the message to the student in behind position, it is consist of goal, materials, and steps of procedure text materials. For example:

Goal: How to Check Mizone's Electrolyte Solution

Materials:

1.Mizone

Tools:

1. Glass Measurement

2. $\mathrm{CH}-\mathrm{CD}$ Electrolyte Solution Test Tools

3. Lamp

Steps :

1. First of all, pour Mizone isotonic drinks into the glass measurement.

2. And the second step, plug in " $\mathrm{CH}-\mathrm{CD}$ Electrolyte Solution Test Tools" into the electricity.

3. Next step, dip "CH-CD Electrolyte Solution Test Tools" into the glass measurement of Mizone.

4. Finally, you can see the result.

5. The lamp flame is very bright.

6. One link in an information chain occurs when one person communicates with another person: A--> B. (Bob Blain, rblain@siue.edu. 2015).So, When the first student accept the first message of procedure text materials from the teacher, he/she delivers the message of procedure text materials to the second student in one sentence by one sentence of the procedure text message.

7. A second link occurs when some of that information is relayed to a third person: A --> B --> C. (Bob Blain, rblain@siue.edu. 2015). Based on this theory, So, the message is relayed to the third student: $A-->B$--> $C$.

8. And then the third student relays the first message to a fourth student.

9. Next, some of that message is relayed to a fifth student.

10. And the last, a fifth student relays the first message to the sixth student. If the group consist of seven or eight person, it can stops to the last number. 
11. After this, sixth student write the first message to the paper and then, see the first message to the cards.

12. Then, He/she can arrange the cards based on the message delivers. They can do it until all of the procedure text materials delivers one sentence by one sentence from the first students to the last student finish.

13. After all of the message are delivered well to the sixth student, and he/she finish arrange the cards. The next step is all of person in a group discuss, what "CH-CD Electrolyte Solution Test Tools" will be used to practising of speaking in procedure text. It is depend on the content of the message given. If the content, consist of electricity, they can choose "CH-CD Electrolyte Solution Test Tools" in Alternating Current (AC) tool, and if the content of the message consist of the anode and catode, it must be a "CH-CD Electrolyte Solution Test Tools" in Direct Current (DC) tool.

14. And the winner is the group where their chain can continue to lengthen as long as some of the information that originated with $A$ continues to survive the communication process. They can survive from the two problems of information chain communication, they are entropy and volume. Entropy refers to the tendency of all messages to be distorted as they pass from person to person. Volume refers to the length of messages. The more details in messages, the more effort people must expend receiving, interpreting, and relaying them.

\section{Conclusions}

Based on the research the games which are available and needed for teaching spoken procedure text to twelfth graders of Senior High School is fun activity. Fun activities is necessary for students to provide a new nuance for students, increase students' interest in learning to improve students' character. So, the researcher decided to develop speaking of procedural text material containing fun activities.In this case, the researcher will use three kinds of fun activities from the highest score, namely " $\mathrm{CH}-\mathrm{CD}$ Electrolyte Solution Test Tools" game using AC (Alternating Current) and DC (Direct Current) of electrolyte solution test tools.

"CH-CD Electrolyte Solution Test Tools" game for teaching spoken procedure text to twelfth graders of Senior High School developed into a teaching material, entitled "CH-CD Electrolyte Solution Test Tools" game. The teaching material was developed as well as the lesson plan given through the flow of learning process, which was implemented as the field testing in class. It is in a form of hand book or module. It is completed with the activities for each stages of scientific approach. Starting from the apperception, as the early step to build students knowledge of the material discussed. The Module has some pictures come with the questions as the stimulus of brain storming. For this 
purpose the book is completed with " $\mathrm{CH}-\mathrm{CD}$ Electrolyte Solution Test Tools" game as the media of presenting the materials. These were all validated by the experts of English department. In developing speaking of procedure text material containing fun activities for the twelfth graders of Senior High School, the researcher used Borg and Gall's model and the steps are possible to be modified when running the program. The steps are conducting need survey, planning, developing material, doing first revision, trying out, doing second revision, producing final product.

"CH-CD Electrolyte Solution Test Tools" game implemented for teaching spoken procedure text to twelfth graders of Senior High School was given to find out which group could deliver right and complete of chain message, match to the cards, and practice to the electrolyte solution test tools.

The use of "CH-CD Electrolyte Solution Test Tools" gamefor teaching spoken procedure text to twelfth gradersof Senior High School is effective, the researcher found that student's attitude improvement run fluently. There were no significant problems on it. The result is that most of the students behaved in a good way. Students were very excited, they involved in the process of teaching and learning actively. During the process of field testing in the classroom, the researcher observed students' attitude by giving the observation check list. The purpose is to build a good character which can be an alternative way for students to accustom in behaving properly. The character values which were going to be developed hereare honest, communicative with teachers, self-confident and discipline. " $\mathrm{CH}-\mathrm{CD}$ Electrolyte Solution Test Tools" game could strengthen the character education, such as honest when they play the game, communicative when they deliver the chain message to the other students in practising " $\mathrm{CH}-\mathrm{CD}$ Electrolyte Solution Test Tools" game, self-confidentwhen they feel confident in matching the message to the cards and pronuncing some difficult words, discipline when students are very excited to be involved in the process of teaching and learning actively and can do the assignments at the target time.

\section{References}

Agustina, Eliasanti. (2014). "Doll Steps" As a Brainstorming Game to Improve The Speaking Skill in Procedure Text of The Ninth Graders of SMPN 1 Mojokerto.Vol 2, No 2 .

Arikunto, Suharsimi. (1996). ProsedurPenelitian, SuatuPendekatanPraktek. Jakarta: PT RinekaCipta.

BadanStandarNasionalPendidikan. (2006). PanduanPenyusunanKurikulum Tingkat SatuanPendidikanJenjangPendidikanDasardanMenengah. Jakarta: BSNP.

Blain, Bob. (2015). The Information Chain Theory. Email: rblain@siue.edu.(retrieved at 1 January 2015)

Borg, W.R \& Gall, M.D. (1983). Educational Research: An Introduction. New York: Longman, Inc. 
Brown, J.D. (1995). The Elements of Language Curriculum: A Systematic Approach to Program Development. Boston, Massachusettes: Heinle\&Heinle Publishers.

Chandler, Daniel, An Introduction of Genre Theory, Retrieved on Monday, March $22^{\text {nd }} 2010$ at 11.03 from http://www.aber.ac.uk/media/Docunents/ intgenre1.html.

David Nunan. 1992. Research Method in Language Learning. New York: Cambridge University Press.

Febriyanti Siti Aulia, Arifin Tina Mariany. Improving Grade X Students' Speaking Competence In Reporting A Procedure Text By Using Video CAR. Binjai. Jambi.Vol 2, No 14.

Harmer, J. (2001). How to Teach English (An Introduction to the Practice of English Language Teaching. Edinburgh : Longman.

Johnson, D.W., R.T. Johnson, \& E.J. Holubec. (1993). Cooperation in the Classroom ( $\left.6^{\text {th }} e d.\right)$. Edina, MN: Interaction Book Comapany.

Lounsbury, J.H. (2000). Understanding and Appreciating the Wonder Years.Retrieved from National Middle School Association Web Site (www.nmsa.org) on September 25.

Mulyasa, E. (2006). KurikulumBerbasisKompetensi: Konsep, Karakteristik, danlmplementasi. Bandung: PT RemajaRosdakarya.

Nurhasan. (2011). Teaching Speaking Procedure Text Using Pictures reports. Thesis. Bogor: University of Ibn Khaldun.

Oller, John. W. (1979). Laguage Tests at School: A Pragmatic Approach. Boston, Massachusetts, USA: Longman.

Raihani. (2007). Education reforms in Indonesia in the twenty-first century. International Education Journal, Vol.8 (1), pp. 172-183. Retrieved from http://ehlt.flinders.edu.au/education/iej/articles/v8n1/Raihani/paper.pdf on September 22, 2013.

Richard, J. C. (2008). Teaching Listening and Speaking from Theory to Practice. USA: Cambridge University Press.

Saleh, Mursid. (2008). Enam Tradisi Besar Penelitian Pendidikan Bahasa. Semarang: Universitas Semarang Press.

Scott, W.A. \&Ytreberg, L.H. (2003). Teaching English to Children. In Neville, G (Ed.), Listening. New Yok: Longman. pp. 21 - 22.

Sudjana. 2001. Metode Statistika. Bandung: Tarsito.

Sukestiyarno. 2013. Olah Data PenelitianBerbantuan SPSS. Semarang: Unnes.

Widdowson, H.G. 1972. The Teaching of English as Language Communication. In Brumfit and Johnson. 